\title{
HERITAGE AND SUSTAINABLE DEVELOPMENT IN BEIRUT: A NEW ECOLOGY FOR THE CITY
}

\author{
Nada El-Khoury \\ Lebanese American University, Faculty of Architecture \& Interior Design, Beirut, Lebanon
}

KEY WORDS: Heritage, Sustainable Development, Ecology, Ecocity, Beyrouth, ICT

\begin{abstract}
:
The objective of this reflection is to consider heritage as a model for sustainable development, whereby its appreciation contributes to the well-being of the city's citizens that we call Ecocity. The development challenges of Beirut, a city that is being reconstructed at an astounding speed after a civil war that modified a number of social values, highlights the objective: to create a link between heritage conservation, which considers the built environment and its functions, and sustainable development. In fragile urban environments such as Beirut, heritage must be considered as an inheritance to be at once preserved and encouraged to thrive. The city is at once a material and immaterial space which benefits from a global vision. The Ecocity is then the result of a balance, ever unstable, between the built environment and human requirements that alter over time. However this socio-economic evolution should not be considered in a negative light, as a healthy city is dependent on diversity and a respect for the balance between the built environment and its inhabitants. In fact, built heritage has always been diverse, however it has always found resolution by weaving together the lifestyles of its inhabitants with the local culture. These reflections have the capacity to pave the way for a reinterpretation of heritage conservation as a dynamic activity and viewing sustainable development as a contribution to growth of Ecocities.
\end{abstract}

\section{INTRODUCTION}

This paper presents the results of a multidisciplinary research project that combines the fields of architecture and the conservation of the built heritage, history, communications and computer science in the development of an Ecocity. In general, an Ecocity is an ecologically healthy city. In the particular context of our research it is associated with the idea of Green design that has been defined as Green as the means of allowing people to become more in touch with the environment in which they live. It takes into account natural landscapes and all the environmental effects. It is based out of creating buildings, which fit into their natural surrounds and give people a sense of place. Many of the key components of green design involve indepth knowledge about a place. Knowledge of local environments is very important and Green buildings must account for sun intensities, temperature variation, precipitation and many other environmentally driven aspects. (R. Ludlow, 2007) Green design was an action naturally done by previous civilisations and our research project main objective is learning ecological insights and know-how from the previous generations. It is also about learning from the past by preserving its traces through a sustainability vision.

This study of new methods of experimentation will enable us to define and validate new orientations in the way we understand, structure and transfer acquired knowledge about a given architecturally significant complex leading to the development of an Ecocity. The aim of the project is to present the various experiences obtained during the interpretation of heritage spaces, using information and communication technologies. More specifically, it involves acquiring, through ICT, computer modelling and archaeologists' accurate documentation, an understanding of a sustainable vision established as the consequences of successive occupations of a historical city. It also seeks to gain a better understanding of the construction techniques and ecological know-how of the Ancients. The objective of this project is to introduce computer modelling, which is capable of showing the city's evolution over the centuries, in order to help us understand the city and how to move towards an Ecocity. This work will reflect on how to respond to certain challenges using the example of the experiences acquired at the site of the ancient city of Beirut in Lebanon. The Beirut project also helps to re-create and remould a city without having all the information and to test hypotheses that we would otherwise be unable to validate without compromising the heritage values of a site by physically reconstructing it. Such a compromise was experienced in the case of the district of Gemmayzé in Beirut which includes streets characterized by heritage buildings (Jidejian, 1993). (Figure 1)

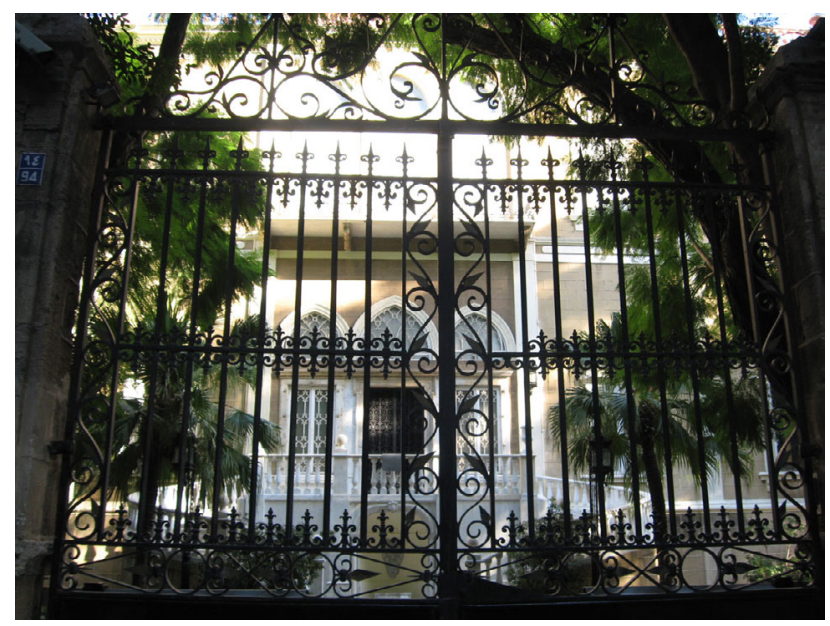

Figure 1: One Building in the district of Gemmayzé

As a first step, we organized and described approaches for the transfer of knowledge that allowed us to exploit representations 
of spaces with the help of digital modelling software. We then developed the information structure necessary to validate strategies for defining an informative representation interface, using software applications that enabled us to create web-based interactive digital devices. Starting with the modelling of the street, we tried to identify buildings within this space by including text data and images. This itinerary proposes web content where the user can interact with the proposed interface and find out in real time where the heritage places are located depending on the action selected. This interface can display the various layers and forms of a place. So as to allow the user to learn through interaction with the digital modelling systems and by experiencing friendly interfaces (Zreik, 2005).

Our method aims to provide new solutions using technological means, with an emphasis on information gathered on a future ecocity. By using this approach, we hope to present a cognitive and interactive device which enables the users to identify sustainable architecture (Khayat, 2001). This system has the advantage of providing information on the site's location, its shape and future threats in order to stimulate action leading to its protection and to how to transmit it to future generations.

On the basis of our research results, we propose an initial digital model. This model allows the user to clearly identify and communicate cultural heritage spaces and how important they are for the development of an Ecocity. Subsequently, a final computer model is proposed which would meet the user's target requirements more adequately. (Figure 2) The results we propose lead us to believe that we can rely on computer tools to communicate the importance of an Ecocity. Subsequent research contributes to the development of digital devices that can enable the communication of heritage spaces in the development of an Ecocity.

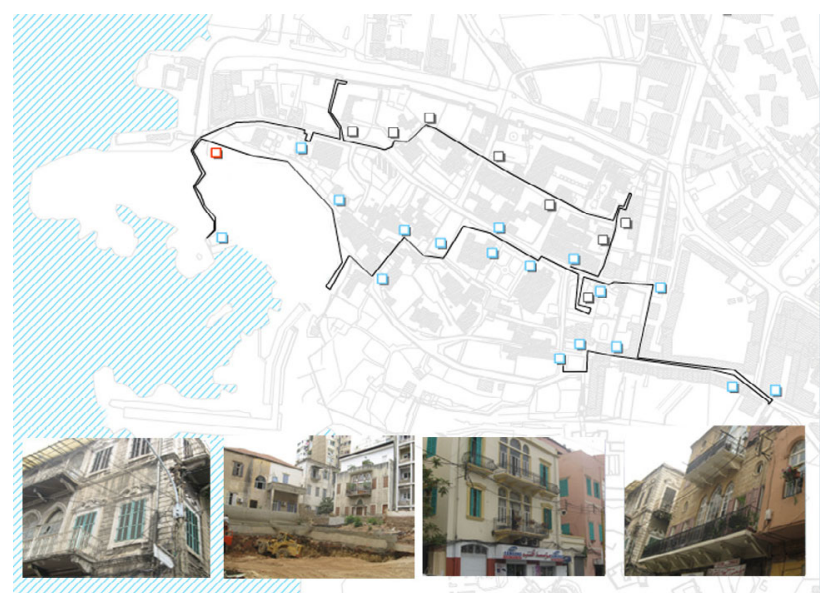

Figure 2: Itinerary tracing heritage buildings in the context of a future Ecocity : Beirut (El-Khoury, 2010)

\section{BYBLOS ANOTHER ECOCITY}

The idea of the Beirut project was inspired by another research project: the Byblos project at the University of Montreal (ElKhoury, 2008; De Paoli \& all., 2007, El-Khoury 2010). (Figure 3) This research project also deals with the use of information and communication technologies (ICT) in the enhancement of architectural heritage as an example of sustainable architecture, particularly in the case of the Byblos site in Lebanon.

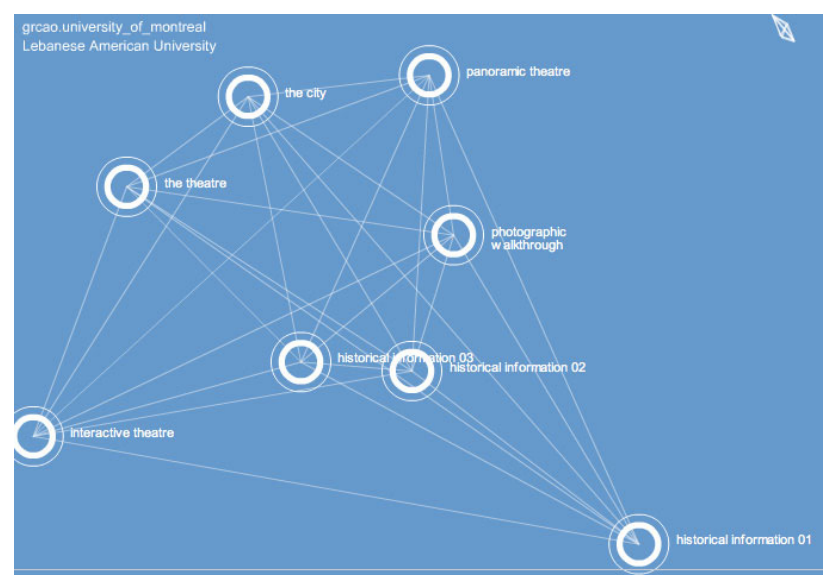

Figure 3: Byblos project at the University of Montreal (ElKhoury, 2008; De Paoli \& all., 2007)

Located north of Beirut, the city of Byblos, which has been included on UNESCO's World Heritage List since 1984, boasts a number of lively, ancient neighbourhoods, as well as an archaeological site where excavation work has unearthed a succession of abandoned cities revealing longvanished civilizations (Jidejian, 2004). "The chief attraction of Byblos for visitors is the superposition, in the same site, of ruins spanning 7,000 years of history." (Dunand, 1973). Over the course of history, the site served as a quarry for successive civilizations. Such was the case with the Roman theatre, which was used as a source of stone by the Crusaders (1108) and whose origins date back to 218 A.D. Today, only the first five tiers and the stage remain. When it was first excavated, the theatre faced the setting sun. It was moved and rebuilt near the sea by archaeologists, and is now located at Early Bronze Age period levels. Some of his building'materials were used in the city and the castle. Tensile structures were originally positioned over dressed over the public spaces centuries ago. The purpose of such a structure was, according to archeologist Dunand (1930), to protect the audience from the heat of warm summers. In witness to this fact, holes that support these protective structures were found in the stones on the first steps of the theatre. Poet Lucretius likens the Velarium to a multicolored cloud that gives forth a crackeling noise, resembling fluttering pieces of paper, as it flaps. (Izenour, 1996) According to archaeologists, building materials' taken from the roman theatre of Byblos were used by successive civilisations as bases for their monuments.

The idea for this research (De Paoli, Bronson, Eaton, Bonnechère, 2005) arose from the study of certain ancient sites, of which sometimes only ruins remain, but that are important enough to merit further exploration: these ruins represent an example of sustainable architecture. There are multiple definitions of sustainable architecture, and this a subject of ongoing debate among the various disciplines involved in its development. In our case, we define it as the know-how arising from the construction methods and ways of life that characterize a place through a vision of sustainable development.

Sustainable development is a constantly evolving concept, particularly since 1987 when the World Commission on Environment and Development, sponsored by the United Nations conducted a study of the world's resources after the international recognition of an impending and assured global disaster. According to the UN Brundtland Report, 1987, (Our Common Future): "Sustainable development is development 
that meets the needs of the present without compromising the ability of future generations to meet their own needs ".

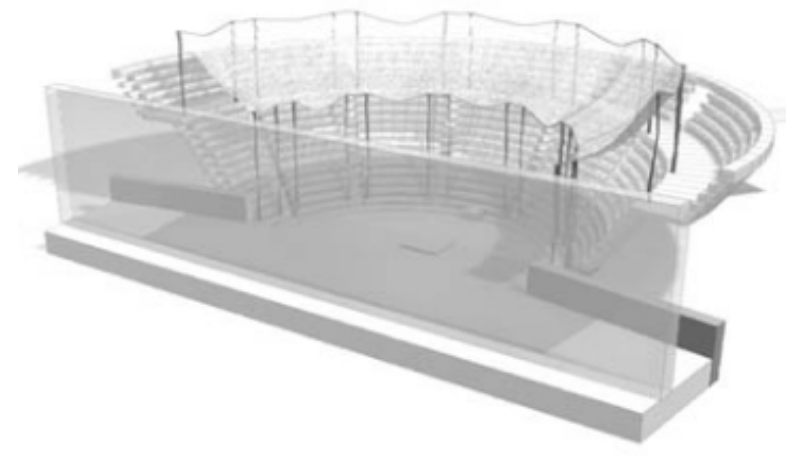

Figure 4. Roman theatre whose origins date back to 218 A.D.

The concept of sustainable architecture is increasingly gaining currency. The preoccupation with what we try to define as sustainable architecture may also contribute to a broader emotional basis of development practice, which can help us in the daily fight against the progressive world-wide destruction and decay of our environment. Sustainable architecture is not a static value, but an evolutionary concept. The notion of Sustainable architecture must not be fixed at a particular point in time - it is dynamic and evolves. Therefore it is important to look back in the past and learn from ancient civilizations and sustainable architecture.

These new approaches to sustainable architecture have guided our experimentation in developing new digital devices to understand Ancient environmental know-how through ICT. Old civilizations had the knowledge of local environments. They knew how to incorporate natural landscapes into the buildings design, which give people a better connection to the land. They also took into account creating monuments and buildings which fit into their natural surrounds and give people who use them a sense of place, as opposed to conventional architecture which pushes people away from the natural environment. Many of the key components of Ancient know-how involve in-depth knowledge about a place. They knew how to examine given conditions (site conditions, climate, daylight, and noise). Today sustainable architecture must account for intensities, temperature variation, precipitation and many other environmentally driven aspects. (R. Ludlow, 2007). In Byblos a sense of place is very present. Lessons from the past are great educational tools that will allow people to get a better understanding of sustainable architecture. Such lessons are a step in a sustainable future.

\section{UNDERSTANDING SUSTAINABLE ARCHITECTURE THROUGH ICT}

One of the main objectives of our research has been to gain an understanding of sustainable architecture in order to demonstrate how, using new methods of representation, we can attempt to virtually represent Ancient know-how, what is and what used to be. ICTs allow for an exploration involving the simultaneous use of simulation and experimentation. With regard to techniques of representation, it should be noted that in the twentieth century architecture was illustrated by means of drawings, plans, cross-sections and elevations produced by architects and archaeologists.
Three-dimensional reconstructions of spaces were often created as well. This is precisely what the archaeologist Maurice Dunand undertook during the excavation of Byblos in the 1930s. His sketch of the Roman theatre of Byblos is one example of this approach. It is prominently featured on a sign providing information about the architectural heritage to visitors (Figure 5). Graphic reconstitution in the form of drawings is still widely used today for the enhancement of architectural heritage. (De Paoli, El-Khoury, 2005a)

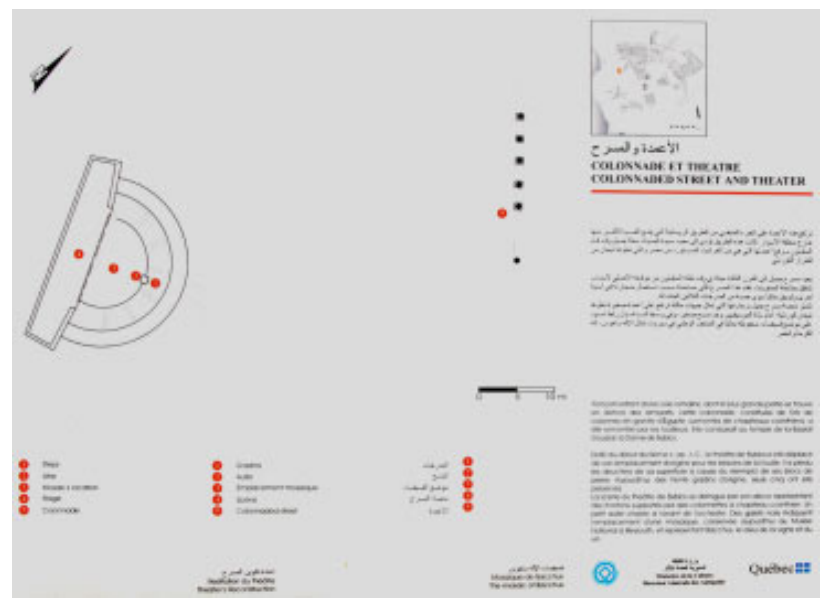

Figure 5: Sign providing information about the architectural heritage to visitors (Byblos site)

The restoration of ancient monuments is another way in which architectural heritage can be enhanced. Restoration, according to Pérouse de Montclos, involves a number of different areas. These include "consolidation", which is done to ensure a building's durability, without modifying it; "reassembly", the reconstruction of a building whose parts are still available onsite; "reconstitution", the collection and reassembly of authentic elements that have been dispersed; and "repair", the replacement of deteriorated parts with new, identical elements. (Gillot, 2006) The physical reconstitution of monuments is now regulated. The Venice Charter, which preceded the one adopted in Victoria Falls in 2003, states "that architectural heritage must be considered within the cultural context to which it belongs, that conservation and restoration of architectural heritage requires a multidisciplinary approach, and that the latter is not an end in itself but a means to an end, which is the building as a whole."

Finally, it should be recalled that, as with life-size reconstructions, scale models also are potential tools for enhancing architectural heritage. They can be used to depict a building, but often provide no information on the factors related to its construction history. Such models are limited to threedimensional reconstitution of forms that are, in certain cases, hypothetical. They are often used as teaching aids, and also as tools to inform and entertain cultural tourists. (Gillot, 2006) In this chronology of architectural expression, the use of computer models that allow for realistic simulations and realtime movement through virtual spaces, becomes relevant. Little by little, a physical environment is expressed through digital 3D spaces and a kind of architecture that is virtual and dematerialized sees the light and helps us better understand the construction of a building. 


\section{METHODOLOGICAL EXPERIMENTATION}

In addition to the potential of simulation, virtual space opens new possibilities of expression and experience (Engeli, 2001). It also helps to re-create and remould a monumental complex without having all the information and to test hypotheses that we would otherwise be unable to validate without compromising the heritage values of a site by physically reconstructing it. (UNESCO, ICCROM, ICOMOS, 1994) This was the case of the Roman theatre of Byblos (A.D. 218), which we used as a case. study and which, as previously mentioned, was moved and rebuilt near the sea by archaeologist M. Dunand in the 1930s (Jidejian, 2004) In order to better understand the architectural heritage of Byblos' Roman theatre, a preliminary experiment was undertaken based on a multidisciplinary research strategy. This strategy allows the development of augmented reality experiences in order to make us feel present within old constructions as well as on the actual archaeological site. Based on the 3D models and photos taken from known positions on the site, we built $360^{\circ}$ cylindrical panoramic photos related to specific coordinates. Then, through the different configurations of the building, several layers of the theatre were composed on the present site view.

The activity of comprehension and communication inside this dynamic virtual historical space is more intuitive and effective than using only abstract technical data for plans and orthogonal views. Furthermore, with ICT, we are able to remotely access these augmented realities. It will also be possible to experience them in an immersive way using projection systems, placing the participant directly in the past while respecting the user scale. In addition, sound effects may be added to enhance the sense of presence. This prototype can also be shared online within the researcher community. (De Paoli, 2005b, Khayat, 2006, ElKhoury, 2010 ) (Figure 6)

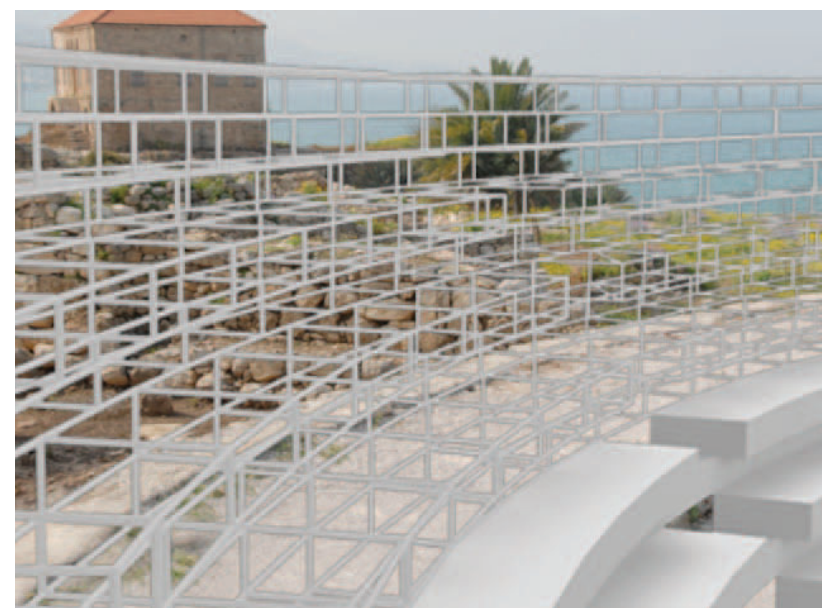

Figure 6: 3D models; corrected perspectives using QTVR.

Based on these research results, which draw their validity from the know-how of the architectural past, we are able to generate figurations of similar theatres: the researcher operates within a paradigm that brings together various types of solutions by means of "figurations". The use of parametric functions enables us to break down the construction process. The result is an approach that integrates various design process "operators" to enable the use of appropriately structured figurations that can be manipulated, transformed and organized into a figuration of the object. This process is somewhat similar to the reuse of architectural knowledge in the creation of an architectural work.
In designing a new project, architects use fragments of knowledge derived from ancient structures, whether these fragments are reutilized, or simply projected. The design is then based on the memory of a previous interpretation, since the extraction of reusable knowledge can be achieved through an interpretive process. (Leglise, 2000) It is with a view to reusing such knowledge that we take up and further explore this way of representing know-how in the case of the theatre of Byblos. It is important to note that our intention to transfer ancient knowhow does not affect the situation of those researchers who are neither archaeologists nor tourism promoters, but who are attempting to understand the architectural heritage. Our goal is to propose methodological experiments to define and validate new orientations in the way we understand, structure and transfer the knowledge associated with a given site.

As a first step, we organized and described approaches for the transfer of knowledge that allow us to exploit representations of spaces with the help of digital modelling software (Figure 7).
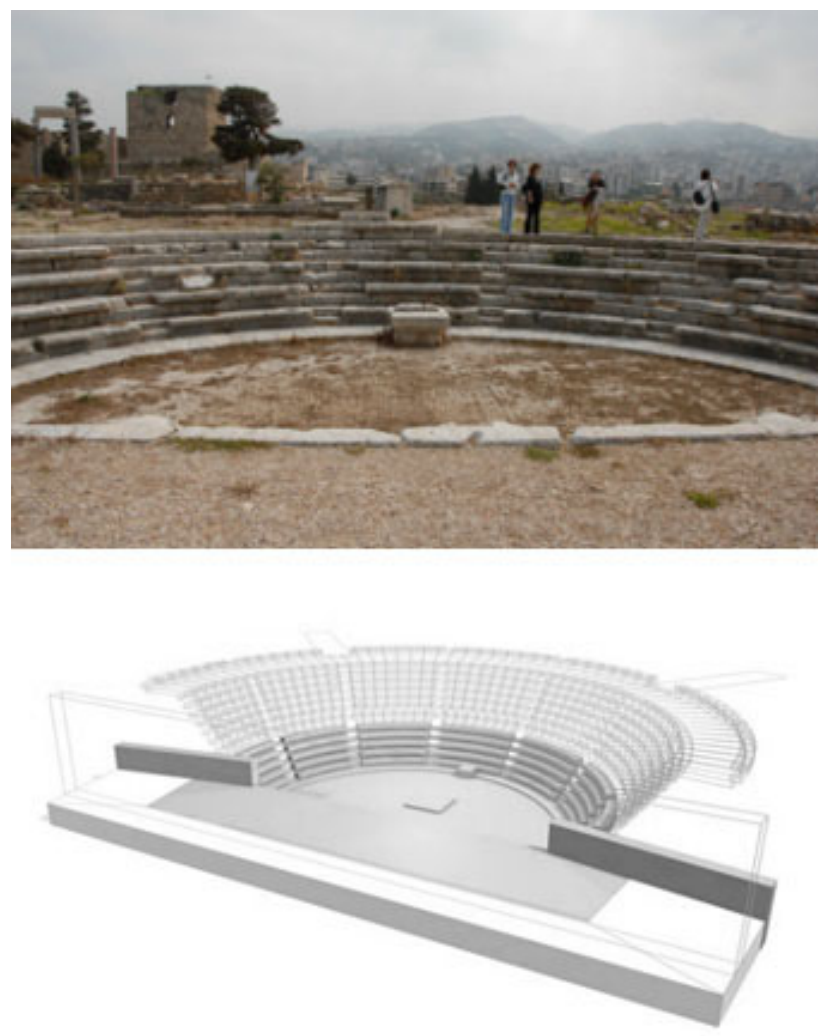

Figure 7: Representations of spaces (analogical and digital)

We then developed the information structure necessary to validate strategies for defining an informative representation model, using software applications that enabled us to create web-based interactive digital devices. As shown in Figure 8, these experiments enable us to deepen our knowledge of the construction techniques and know-how of the Ancients, and to create computer models that illustrate the site's evolution over the centuries, to help us better understand the superposition of historic layers and suggest periods to which the research proposal might be applied. : the virtual reconstruction of the theater is linked with the site's evolution over time and connected to the urban development is visible in the real time animation achieved through this research project (http://www.arclab.umontreal.ca/BVM/) 


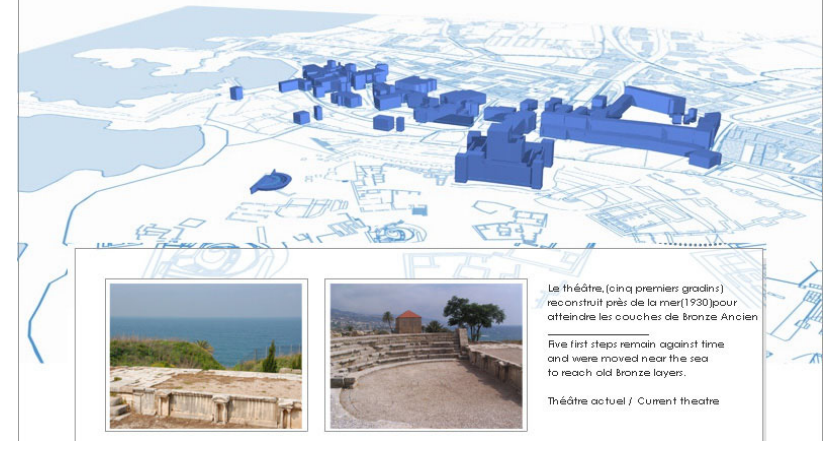

Figure 8: Site's evolution: historical documents and digital representation (http://www.arclab.umontreal.ca/BVM/))

In order to develop modelling methods that take advantage of new information technologies, and to achieve our project's stated objective of designing computer-based approaches for representing the spaces that evoke the memory of a site, we generated an initial computer model of the theatre, in which the steps that have survived to the present (in darker colour) can be distinguished from the rest of the theatre as it might have appeared at the time. Based on this work, the reconstituted theatre was replaced in its original context, as it might have existed before it was taken apart and moved. The way in which these objectives were achieved will likely have a impact on the current work methods of the designers involved in the development of the Byblos site, as they can now benefit from the integration of information relating to the know-how of archaeologists, architects and historians to colligate a memory and propose new methodological orientations in the restoration of the man-made environment.

\section{CONCLUSION}

Through this work we explored different avenues to achieving the goals set forth in the research project. Our initial desire to understand sustainable architecture led us to delve further into the concept of architectural heritage and review previous work that had been done on the topic. This reflection process enabled us to define the themes for the Byblos research project by orienting its focus on the case of the Roman theatre. We realized that, although they are two different entities, the city of Beirut and the city of Byblos share a common concern: how to move towards an Ecocity. Experiments done through this research answered the main goal of this project.

We reflected on the types of solutions that could be brought to bear. Our conclusion is that research must not lead to the automatic generation of solutions. Rather, its aim is to provide a means of understanding spaces for the enhancement of local sustainable architectural heritage, using information and communication technologies. The reconstitution of a building facilitates not only the understanding of its ruins, but also the dialogue between professionals and nonexperts. The creation of 3D models provides a new opportunity for researchers and the public alike to better understand sustainable architecture. This work opens up perspectives for research that we will touch on briefly. These can be organized around two distinct poles.

The first relates to the future of architecture education, which is an essential function of a site such as Byblos if it is considered as a museum. From this standpoint, the question of how knowledge will be transmitted in the future is at the forefront, and researchers are asking themselves what type of museum should evolve in the years ahead. Will we see an "info-highway museum" in which data can be manipulated but not modified? Or a "museum without walls" that will be able to reach people wherever they are? (Allard, 1997). Heritage education is a key element in the creation of an open environment museum space, as in the case of Byblos, which opens onto the city. Knowledge is thus transferred in a kind of museum entertainment.

The second pole is the adoption of an interdisciplinary vision in the development of sustainability and outreach initiatives to better reflect the richness and subtlety of the content. Research perspectives are not limited to these two poles but extend to other areas as well. For instance, the results of this research project could be used for pedagogical purposes. Teaching sustainable architecture and design could be made more accessible by means of models to aid in our understanding of these sites.

It is in this direction that we continue our methodological experimentation; our aim is to contribute to the advancement of knowledge by integrating the expertise of the various disciplines involved in the enhancement of Ecocities, which can only be enriched as a result. ITCs become a unifying element between these different fields and thereby help to facilitate the process of shared decision making in environmental issues. "....we must at the outset take note of the countries and climates in which buildings are built." Vitruvius, Architect 110 B.C. (Stitt, 1999)

\section{References}

Allard, M., Boucher S., 1997. Prolégomènes au développement de modèles théoriques de pédagogie muséale. In Le musée, un lieu éducatif, Musée d'art contemporain de Montréal, Montreal.

Biblos.Virtual.Museum,

http://www.arclab.umontreal.ca/BVM/(accessed 9 August 2012)

De Paoli G, El Khoury N. 2005a. ICT and the Ancient City of Byblos : A new Direction for the Communication of Intangible Heritage. In Augmented Heritage, Europia Production, Paris.

De Paoli G, El Khoury N. 2005b. L'arrière-scène du théâtre romain: le cas de Byblos au Liban. Virtual Retrospect, Collection «Archéovision» de l'Institut Ausonius, Bordeaux, pp. 18-22.

De Paoli G. (et.al.), 2007. Expériences méthodologiques et validation de nouvelles orientations basées sur des dispositifs numériques pour la création d'un espacemémoire pour l'ancienne ville de Byblos au Liban., Research project CRSHIDR Canada.

De Paoli, G., El-Khoury, N., 2006. The backstage of Byblos' Roman theatre: New Digital Devices using Information and Communications Technology (ICT), 7th International Symposium on Virtual Reality, Archaeology and Cultural Heritage (VAST), Sringer-Verlag ed., Nicosia.

Dunand M., 1973. Fouilles de Byblos, (5 volumes), Librairie orientaliste Paul Geuthner - Librairie d'Amérique et d'Orient, Adrien Maisonneuve, 1939-1973, Paris.

El-Khoury N. (et al.), 2006. Digital Reconstruction as a means of understanding a building's history: case studies of a multilayer prototype, 8. Communicating Space(s), (Proc. eCAADe2006). 
El-Khoury, N., De Paoli G. 2010, Interactive Itinerary of heritage houses in Beirut: walking back to the future, Euromed2010 Digital Heritage 2010, Springer-Verlag ed. Lemesos.

Engeli M., 2001. Bits and Spaces : architecture and computing for physical, virtual, hybrid realms, Birkhäuser.

Gillot C., 2006. La restitution du patrimoine archéologique bâti, aux moyens des technologies de l'information et de la communication, Etat de l'art, Rapport de recherche GRCAO, Contribution d'un moyen informatique à la validation d'hypothèses de restitution architecturale dans le domaine du patrimoine bâti ancien, University of Montreal, CRSH-Canada, Montreal.

ICOMOS 14th General Assembly and Scientific Symposium, Victoria Falls, 2003.

http://www.international.icomos.org/victoriafalls2003/kimberle y_fre.pdf (accessed 9 August 2012)

ICOMOS UNESCO, 1984. Liste du patrimoine mondial N. 295, Bien proposé: Byblos, Liban, ICOMOS, Paris. http://whc.unesco.org/pg.cfm?cid=31\&id_site=295 (accessed 9 August 2012)

Izenour, G.C., 1996. Theater design, second edition, Yale University Press, New Havenn and London.

Jidejian N., 2004 Byblos à travers les âges, Librairie orientale, Librairie orientale, Beyrouth.

Khayat, G., 2006. Le musée d'écriture et du livre, Council of Development \& Reconstruction, Republic of Lebanon, Urban Conservation Design Studies, CDR, AAA Atelier des Architectes Associés, Beyrouth.

Léglise M., 2000. Conception assistée : modélisation et interprétation. In Modélisation architecturale et outils informatiques entre cultures de la représentation et du savoirfaire, Les Cahiers scientifiques N. 95, Acfas, pp. 51-66.

Lodlow R., 2007, "green architecture”, Environmental studies 399 Senior Capstone, St. Olaf college, Northfield, MN, http://www.stolaf.edu/depts/environmental-studies/courses/es399\%20home/es-04/Projects/Ludlow_Project/place.html

(accessed Sep. 2007)

Saleh F. (et al.), 2005. The art of Documenting Heritage, Virtual Retrospect 2005, Collection «Archéovision» de l'Institut Ausonius, Bordeaux, pp. 106-112.

Stitt F., 1999. Ecological Design Handbook: Sustainable Strategies for Architecture, Landscape Architecture, Interior Design, and Planning, McGraw-Hill, New York.

UNESCO, ICCROM, ICOMOS, 1994. Document de la Conférence de Nara sur l'Authenticité. Convention du Patrimoine Mondial, Nara.

Zreik, K., Reza B., 2005. Augmented Heritage : A Sustainable ICT Challenge, Augmented Heritage, New Era for Architectural Design, Civil Engineering and Urban Planning, Edited by K. Zreik, R. Beheshti, O. Fakouch, Europia, France. 